This is an electronic reprint of the original article. This reprint may differ from the original in pagination and typographic detail.

Author(s): Dalton-Puffer, Christiane; Llinares, Ana; Lorenzo, Francisco; Nikula, Tarja

Title: "You Can Stand Under My Umbrella": Immersion, CLIL and Bilingual Education. A Response to Cenoz, Genesee \& Gorter (2013)

Year: $\quad 2014$

Version:

Please cite the original version:

Dalton-Puffer, C., Llinares, A., Lorenzo, F., \& Nikula, T. (2014). "You Can Stand Under My Umbrella": Immersion, CLIL and Bilingual Education. A Response to Cenoz, Genesee \& Gorter (2013). Applied Linguistics, 35(2), 213-218.

https://doi.org/10.1093/applin/amu010

All material supplied via JYX is protected by copyright and other intellectual property rights, and duplication or sale of all or part of any of the repository collections is not permitted, except that material may be duplicated by you for your research use or educational purposes in electronic or print form. You must obtain permission for any other use. Electronic or print copies may not be offered, whether for sale or otherwise to anyone who is not an authorised user. 


\title{
"You can stand under my umbrella": Immersion CLIL and bilingual education. A response to Cenoz, Genesee \& Gorter (2013)
}

\author{
Christiane Dalton-Puffer, Ana Llinares, Francisco Lorenzo \& Tarja Nikula \\ (University of Vienna, Universidad Autónoma de Madrid, Universidad Pablo de Olavide and University of Jyväskylä)
}

Classrooms the world over are full of people who, for different reasons, are learning additional languages and/or are studying through languages that are not their first. Gaining insight into such contexts is complicated for researchers and practitioners alike by the myriad of contextual variables that come with different implementations and make comparison and generalization a tricky business. We welcome Cenoz et al.'s (2013) article as an important contribution to the debate on how best to tackle this problem. In this Forum piece we would like to, however, redress the balance on two issues: the fact that terminologies have histories and the emphases on the research agenda suggested for future Content and Language Integrated Learning (CLIL) research.

\section{Introduction}

Classrooms the world over are full of people who, for different reasons, are learning additional languages and/or are studying through languages that are not their first. We thus welcome Cenoz, Genesee \& Gorter's (2013) article as part of a dialogue on how to best handle the concomitant problem of accounting for a myriad of contextual variables in a way which furthers insight for scholars and practitioners alike. However, we feel the need to redress the balance on two issues: the historicity of terminologies and the research agenda.

\section{Moving on from the terminological puzzle}

We agree with Cenoz, Genesee \& Gorter (2013; henceforth CGG) that the various recent attempts to distinguish between CLIL and immersion in general terms are evidence of a certain degree of confusion and hence a need for clarification. Since every claim that has been made about characteristics of CLIL can be countered with an example that also holds for immersion (ibid., 5-12), it follows that the two terms apparently should best be considered lexical variants. ${ }^{1}$ One could get into a tie about which of the two should be "the proper", i.e. dominant term. However, this is an avenue we do not want to follow as it has already proven to run in circles.

What we are still left with, though, is a conundrum well known to all applied linguists: to serve the requirement of maintaining clarity about the conceptual dimensions of our research while acknowledging that these very constructs simultaneously have a life in society outside academia. The words immersion and CLIL live the lives of words in natural languages: they have histories, migrate from one discourse to another, acquire connotations and generally have fuzzy boundaries. Perhaps, CGG (2013) have lost sight of this dimension as their analysis of the uses of the term CLIL appears blind to its historicity and the different social contexts in which the term has become relevant (policy, teacher education, classroom teaching and research).

\footnotetext{
${ }^{1}$ In fact, recent research comparing CLIL and immersion programs has revealed more similarities between some CLIL and immersion programs than between different immersion programs (Llinares \& Lyster forthcoming).
} 
The beginnings of CLIL as a label have to be contextualized in European integration and in the principle that unity has a foundation in a theory of communicative action (Habermas 1984). Since then, this humanistic philosophy has been the seedbed of European language policy with its well-known key notions of intercultural competence, multiple identities and multilingual citizens. Against this backdrop CLIL was purposefully coined in the mid 1990's because its (then!) a-historicity and value-freeness was hoped to nudge national-level policy makers into accepting education for multilingualism also in regions where this was kept off the political agenda. Other important motivations were: to complement and enhance traditional foreign language education and to open doors to innovative classroom pedagogies also in content subjects. So CLIL is European in the sense that it has been energized by European language policy and ideology and has in turn energized implementations of these policies at local or regional levels. To paint a fair picture one must add that grassroots initiatives at parental and teacherlevel have been happening simultaneously in countless places all over the continent.

To widen the impact of these language policies beyond (supra)national political circles and to enable exchange of expertise across national borders, the early CLIL activists set up transnational network projects for conceptual development and/or teacher education, for which European funds were available. We would argue that the publications criticized as self-contradictory by CGG were mostly conceived of to operate within this hyper-complex sphere of discourse rather than being directed at only the research community.

With a considerable time-lag (triggered by the absence of research-directed funding) empirical research on CLIL implementations visibly started to happen in different national contexts around the mid-2000s.. This empirical research on actual implementations leads us to claim three prototypical characteristics of CLIL in its present state:

- CLIL languages are mostly major or minor international linguae francae (in Europe English, French, Spanish, German). The reasons for the dominance of English in CLIL programmes cannot be sought in the vested interest of researchers but in current society-wide language ideologies which scaffold the hegemony of English.

- CLIL does not happen instead of foreign language teaching but alongside it.

- CLIL is timetabled as content lessons. Consequently it is taught by content-trained teachers who also assess it 'as content'. This we argue, makes it impossible to bona-fide classify CLIL as a type of CBI. Subject-educators would rightly find that paradoxical

Apart from these core features CLIL implementations are indeed highly variable (and they can and do incorporate also minority/minoritized, migrant and bordering languages). We agree with CGG that there is a downside to this flexibility if research findings from one context are uncritically transferred to another. However, this problem is inherent in comparative educational research in general. Naturally we draw the line at misappropriations - which, as Cammarata \& Tedick (2012) report - have also happened to the term "immersion". With regard to CLIL, an even worse misappropriation is happening on the part of the foreign language industry who sell conventional commercial foreign language textbooks with so-called CLIL add-ons (cf. Banegas 2013). 


\section{On research agendas}

We see two main problems in CGG's (2013) critique of CLIL research. One is their suggestion that CLIL studies have not acknowledged the impact of immersion research: on the contrary, CLIL related academic events have often featured prominent immersion researchers and the pivotal role of immersion research for the field has been acknowledged in numerous CLIL publications.

The second problem we see is the authors' apparent lack of awareness that CLIL research has added new foci and carved a new research agenda in ways that have not been equally prominent in work on immersion, particularly by drawing on a range of socio-functional and contextually-situated language theories such as Pragmatics, Text Linguistics, Discourse Analysis, Conversation Analysis, Systemic Functional Linguistics. For lack of space, we draw attention to two areas in particular since these were explicitly brought up in CGG (2013) as not having received attention by CLIL researchers: the role of integration and the role of the classroom as language learning environment.

Perhaps the way the label CLIL foregrounds 'integration' has brought the role of content and language integration to the fore and with it empirical research on the connections between language structures and particular subject content. For example the study of the language of the disciplines and the development of subject literacies has been a research issue since CLIL inception: there are corpus studies of participants' spoken and written language use in several subjects (see, for example, Whittaker et al. (2011) on CLIL students' development in history writing; or Berger (2013) on students' use of L2 and L1 resources while solving mathematical text problems). Many attempts have also been made to find the so called language muscles of content disciplines at all language levels: lexico-semantics, morphosyntax and genre level, involving the application of linguistic models that look at linguistic structure as inseparable from the meanings and functions it conveys (e.g. Llinares et al. 2012; Lorenzo 2013).. In doing this research interest has gone beyond the idea of balancing language and content pedagogies, as brought up in French immersion research (see Lyster's (2007) counterbalance approach), into investigating the processes of how language and content are best taught, learnt and assessed in integration To our knowledge, the nature of content and language integration has not been at the core of the research agenda in other bilingual education contexts to the same extent.

A second major area that CLIL research has been very active in is the study of how content and language are taught and learnt in the actual context of the CLIL classroom. Thus, we have to counter CGG's point that "research is needed that goes beyond examining simply whether teaching content in an L2 or a foreign language promotes L2 competence to examining how teaching content in an L2 works..."(p.16). In fact, a good deal of CLIL research has been concerned with exactly that! (See Nikula et al., 2013, for an overview of CLIL research on classroom discourse).

Furthermore, one must not ignore the wealth of action research and development work (integrated syllabi, integrated lesson plan models, school language plans and school genre maps) produced by European project networks, much of which is freely accessible on-line. A quick search of the following 
key words corresponding with European-funded programs may be informative: CLIL Compendium, ALPME, CLIL Cascade Network, TIE-CLIL, CLIL across Contexts, AECLIL, to mention a few.

Finally, we agree on the urgent need for research collaboration between educational linguists and subject education specialists. However, there is not such an absolute gap in CLIL research on content learning and L1 outcomes as may seem from research published in English. CLIL research published in German, Finnish and Swedish, for instance, regularly involves (subject) education specialists (e.g. Bonnet 2004, Seikkula-Leino 2007, Lim Falk 2008).

\section{Existing bridges and future prospects}

Labels are good for the recognition of research trends, but beyond that, they may lead to the old sociolinguistic game of the labellers and the labelled. Many who have placed their studies under the CLIL heading and used key words like immersion -and the reverse- would feel uneasy about a split between the two. We call for researchers from different research traditions to develop a common nonhierarchical matrix, for the identification of features of bilingual/multilingual education programs all over the world, in order to help researchers carry out comparative studies across contexts (cf. Cenoz's (2009) continua of multilingual education). As true lovers of diversity in language and all human labours, we acknowledge differences but also feel the need of an overarching concept. For us "additive bilingual programs" already in use in taxonomies is good enough, but if, as CGG suggest, CLIL is a better name, we can only extend an invitation, which we will do in this postmodernist times of ours with the pop lyrics that entitle this paper: You can stand under my umbrella.

\section{References}

Banegas, D.L. 2013. 'An investigation into CLIL-related sections of EFL coursebooks: issues of CLIL inclusion in the publishing market,' International Journal of Bilingual Education and Bilingualism DOI: $10.1080 / 13670050.2013 .793651$

Berger, A. 2013. Learning mathematics bilingually. An Integrated Language and Mathematics Model (ILMM) of word problem solving processes in English as a foreign language. PhD Dissertation. University of Vienna.

Bonnet, A. 2004. Chemie im bilingualen Unterricht. Kompetenzerwerb durch Interaktion. Opladen: Leske + Budrich.

Cammarata, L. and D.Tedick. 2012. 'Balancing content and language in instruction: The experience of immersion teachers,' The Modern Language Journal 96/2: 251-269.

Cenoz, J. 2009. Towards multilingual education: Basque educational research from an international perspective. Multilingual Matters.

Cenoz, J., F. Genesee and D. Gorter. 2013. 'Critical analysis of CLIL: taking stock and looking forward', Applied Linguistics. Advance access, 1-26. (doi:10.1093/applin/amt011). 
Habermas, J. 1984. The Theory of Communicative Action. Vol. I: Reason and the Rationalization of Society, T. McCarthy (trans.). Beacon. [German, 1981, Theorie des kommunikativen Handelns. Vol. 1: Handlungsrationalität und gesellschaftliche Rationalisierung. Suhrkamp]

Lim Falk, M. 2008. Svenska i Engelskspråkig Skolmiljö. Ä olmiljl. ig Sprrmiljj i Tv Gymnasieklasser. Acta Universitatis Stockholmiensis. Stockholkholm Studies in Scandinavian Philology.

Llinares, A., T. Morton and R. Whittaker. 2012. The Roles of Language in CLIL. Cambridge University Press.

Llinares, A. \& R. Lyster. Forthcoming. The influence of context on patterns of corrective feedback and learner uptake: A comparison of CLIL and immersion classrooms', Language Learning Journal 42/3.

Lorenzo, F. 2013. 'Genre-based curricula: multilingual academic literacy in content and language integrated learning', International Journal of Bilingual Education and Bilingualism 16/3: 375-388.

Lyster, R. 2007. Learning and Teaching Language through Content: A Counterbalanced Approach. John Benjamins.

Nikula, T., C. Dalton-Puffer and A. Llinares. 2013. 'European research on CLIL classroom discourse', International Journal of Immersion and Content Based Education 1/1: 70-100.

Seikkula-Leino, J. 2002. Miten oppilaat oppivat vieraskielisessä opetuksessa? [How do pupils learn in content and language integrated teaching?]. University of Turku, Publication Series C: 190.

Whittaker R., A. Llinares and A. McCabe. 2011. 'Written discourse development in CLIL at secondary school', Language Teaching Research 5: 343-62. 